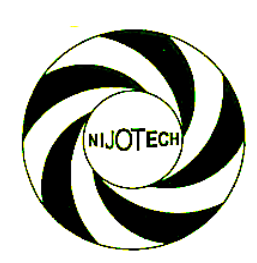

Nigerian Journal of Technology (NIJOTECH)

Vol. 38, No. 2, April 2019, pp. $\mathbf{4 0 1}$ - $\mathbf{4 0 5}$

Copyright@ Faculty of Engineering, University of Nigeria, Nsukka

Print ISSN: 0331-8443, Electronic ISSN: 2467-8821 wWw.nijotech.com

http://dx.doi.org/10.4314/njt.v38i2.16

\title{
AN INVESTIGATION OF THE HARMONIC EFFECTS OF NONLINEAR LOADS ON POWER DISTRIBUTON NETWORK
}

\author{
T. A. Abdul-Hameed ${ }^{1, *}$, M. F. Akorede ${ }^{2}$, Y. Abdulrahman ${ }^{3}$ and O. M. Tijani4 \\ 1, Dept. of Electrical \& Electronics Engineering, Federal Polytechnic, Ede, Osun State, NiGeriA. \\ 2, 3, 4, DePT. OF EleCtrical \& EleCtronics ENGINEERING, UNIV. OF ILORIN, ILORIN, KWARA STATE, NIGERIA. \\ E-mail addresses: ${ }^{1}$ kunleoluyori@gmail.com, ${ }^{2}$ mudathira30@gmail.com, \\ 3 abdulrahmanyusuf35@gmail.com 4 tomeprojects@gmail.com
}

\begin{abstract}
Nonlinear loads are loads that defy ohms law. As a result of changes in impedance, the voltage and current waveforms from the loads are distorted and may be unpredictable in behavior. Heavy presence of a nonlinear load or the presence of many nonlinear loads in a distribution network may significant/y introduce harmonics into such network. Harmonics are waveforms whose frequency is an integer of the fundamental frequency. When present in large quantity, harmonics may cause adverse effects not only to other loads on the network but also to the power distribution network. This paper investigates the harmonic effects produced by nonlinear loads on power distribution network. Nonlinear and linear loads were modelled and developed. Using MATLAB/SIMULINK simulation technique, the system was observed to be unstable with un-periodic oscillations and the total harmonic distortion (THD) was found to be 112.04\% at maximum.
\end{abstract}

Keywords: Harmonics, Distortion, Negative effects, Simulation, Nonlinear Load

\section{INTRODUCTION}

The study of harmonics, its negative effects and possible solutions has been on the increase since late 1980 s when power electronic loads started becoming popular for their efficiency, reliability and controllability. It has been observed that the introduction of nonlinear loads causes deterioration in power quality [1] [2]. One of the major factors that are responsible for the deterioration is the distortions in voltage and current waveforms due to harmonics. This study is a verification and validation of the negative effects of nonlinear loads on power distribution network.

In [3], a review on the essence of making a detailed analysis and appraising harmonics and its effects on power distribution network was made. Many approaches towards mitigating harmonics such as application of phase shifting transformers, harmonic filters, etc. were prescribed as viable solutions. Electrical Transient Analysis Program (ETAP) computer package was used to evaluate their performances.
A MATLAB/SIMULINK software tool was used in [4] to understudy harmonics in power distribution network. The electrical behavior of the network was studied before and after introduction of active filters. The optimal filter among the filters considered was obtained through MATLAB/SIMULINK simulation tools. A MATLAB/SIMULINK wind farm model was developed to generate and analyze several frequencies and magnitudes of voltage harmonics in [5]. It was concluded that the use of Butterworth, Chebyshev and Cauer filters in their various forms are possible and efficient solutions to the mitigation of high order harmonics.

How important the software and hardware tools are to the study of harmonics and its mitigation were well discussed in [1]. Power system harmonics and its impacts were also discussed in [2]. A study on the application of passive filters to mitigate power quality problems as a result of harmonics from induction furnaces was carried out in [6]. The induction furnaces was modelled in ETAP software and the details of the

* Corresponding author, tel: +234-803-396-8572 
power quality problems were investigated. In [7] an extensive review of power system harmonics in the petrochemical industries was done.

Mitigation of harmonics in industrial power system was investigated in [8]. MATLAB/SIMULINK simulation with and without the use of passive filters were carried out and it was established that the introduction of the filters improved the power factor and reduced the current harmonics from $20.77 \%$ to $4.32 \%$.

Studies in [9] presented a topology for reactive power compensation and harmonic mitigation of distribution system using Shunt Active Power Filter (SAPF) compensator. Using Fast Fourier Transform (FFT) analysis on the source and load current, it was established that the power factor of source is near unity and harmonic content on source side are well below the harmonic limit imposed by IEEE std. 5191992.

The application of the instantaneous active and reactive power $(p-q)$ theorem and elongation $(p-q)$ theorem to mitigate harmonics and its impacts on electric power using the active power filter (APF) topologies was central to the work in [10]. APF-solar photovoltaic system with the shunt APF were recommended as viable options in mitigating harmonics.

A selective harmonics elimination (SHE) method to mitigate low order harmonics in multi-level inverters with different loads was developed in [11]. The inverters were realized by cascading $\mathrm{H}$-Bridge in MATLAB/SIMULINK. In order to optimize the switching angles for improved quality in the output voltage, the Bee algorithm was utilized. The Total Harmonics Distortion was reduced to about $10 \%$.

The design and analysis of a 24-pulse ac-dc power autotransformer based converter that employed a pulse doubling technique for asynchronous motor drive was carried out in [12]. Low harmonic distortion and approximate unity power factor were obtained.

A multi objective optimization models with relevant constraints for Passive Power Filters (PPF) and Hybrid Active Power Filters (HAPF) set at high voltage levels were formulated for harmonic filtering and reactive power compensation in [13]. A bacterial foraging algorithm (BFA) was formulated to solve the problems. Harmonic Mitigation in power distribution network Using Active Power Filter (APF) was carried out in [14]. Active and Reactive power (PQ) theory for controlling APF currents was utilized for harmonic mitigation at point of common coupling (PCC) to maintain power quality. MATLAB/SIMULINK models were developed.
The total harmonic distortion (THD) was found to be within nominal values when APF was connected to the system with nonlinear loads and the results validated an effective application of shunt APF for different load conditions.

The effects of triplen harmonics in the Electricity Company of Ghana (ECG) distribution system was researched into in [15]. The performance of three harmonic suppressors in the control of harmonic emission levels in three ECG's distribution transformer substations were studied. The results of the research proved that the neutral blocking harmonic filters can reduce harmonic current in neutral conductors by $88 \%$ and consequently decrease harmonic energy loss by $97 \%$.

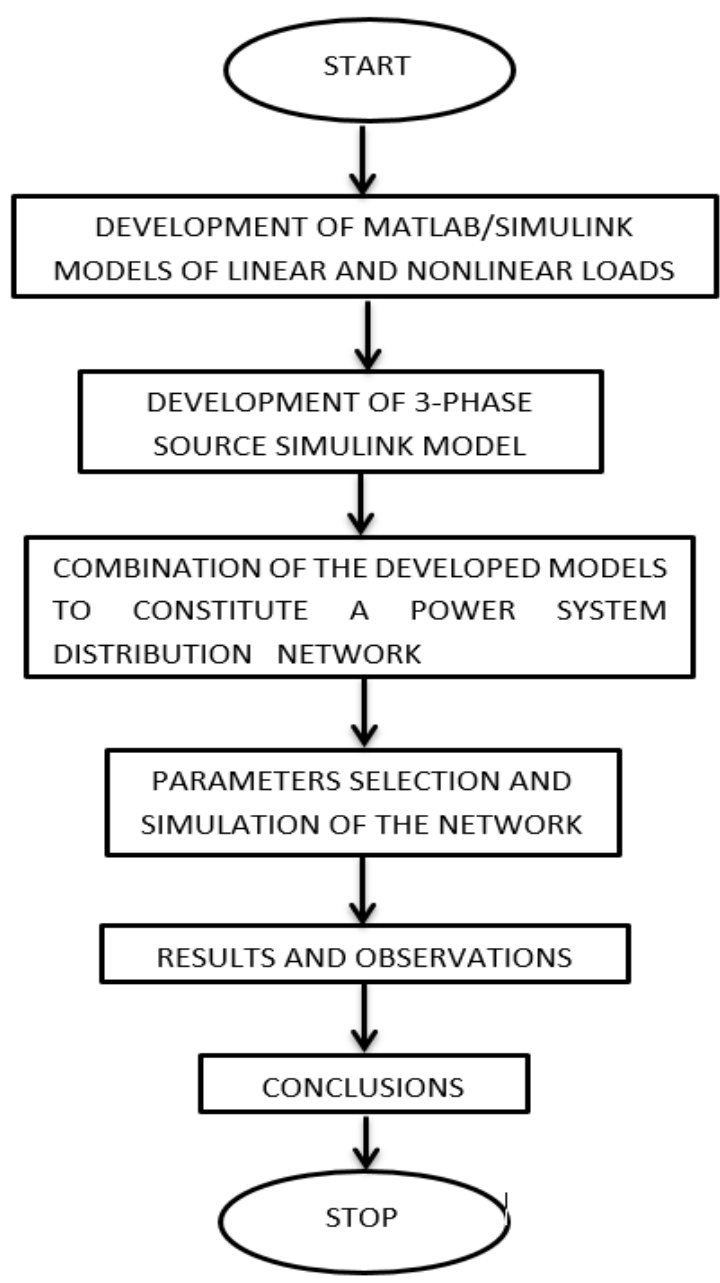

Figure 1: A Step by Step approach towards investigating the harmonics effects of nonlinear loads on power distribution network.

\section{METHODOLOGY}

The following steps are taken to understudy the negative effects of nonlinear loads on power distribution network using MATLAB/ SIMULINK software: 
1. A bridge configured nonlinear load model was developed using three phase bridge connected diodes.

2. Using three phase series RLC branch link the linear loads were modelled and configured.

3. The nonlinear load model was converted to a subsystem.
4. The Voltage-Current measurement Block Model was called out from the Simulink Block Library.

5. All the individual models that constitutes the Distribution Network were connected appropriately.

6. Simulation and observations of the wave distortions from the scope were done. These steps are as illustrated in Figure 1.

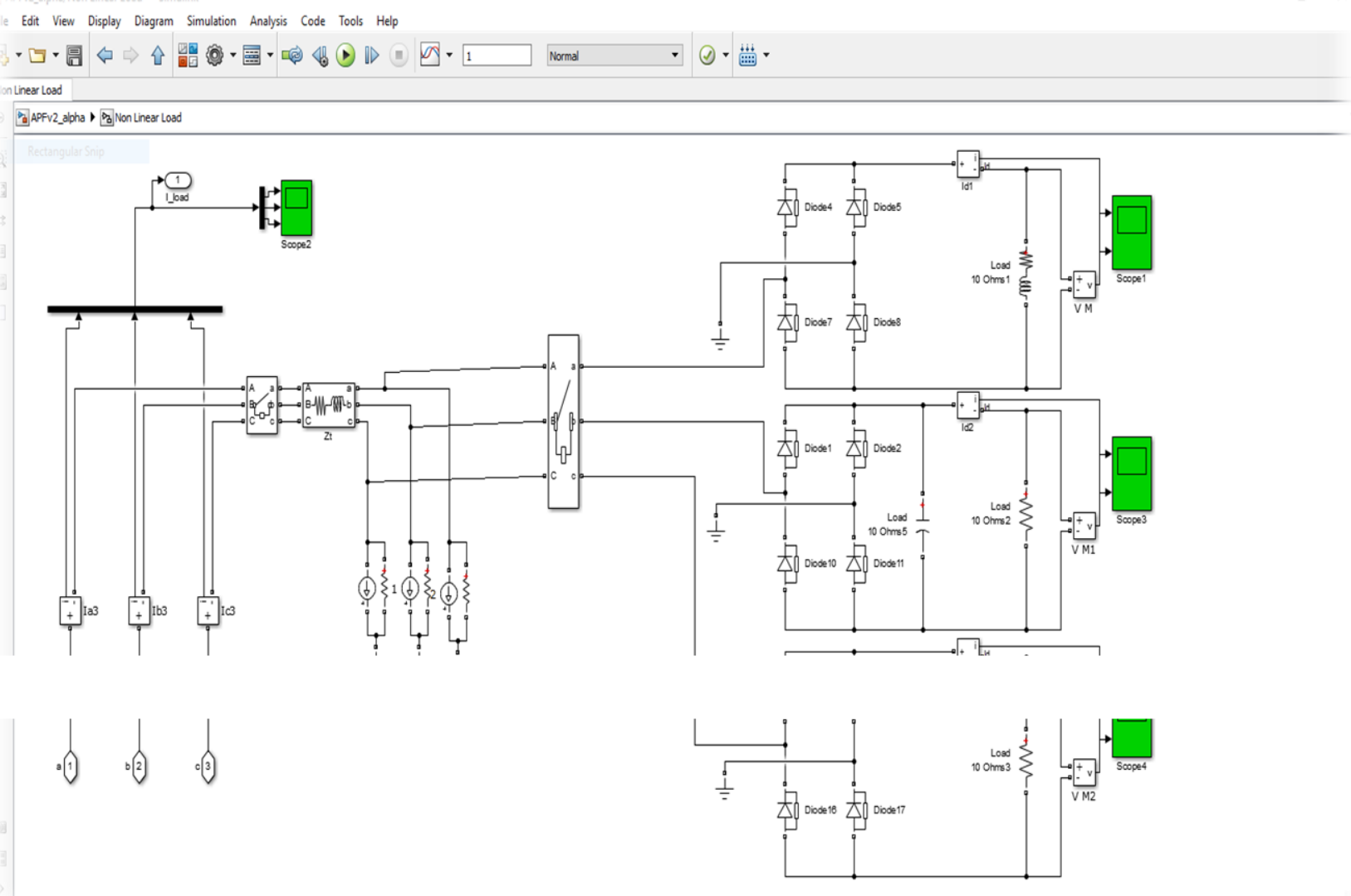

Figure 2: The Simulink model of a 3-phase bridge Configured Nonlinear load.
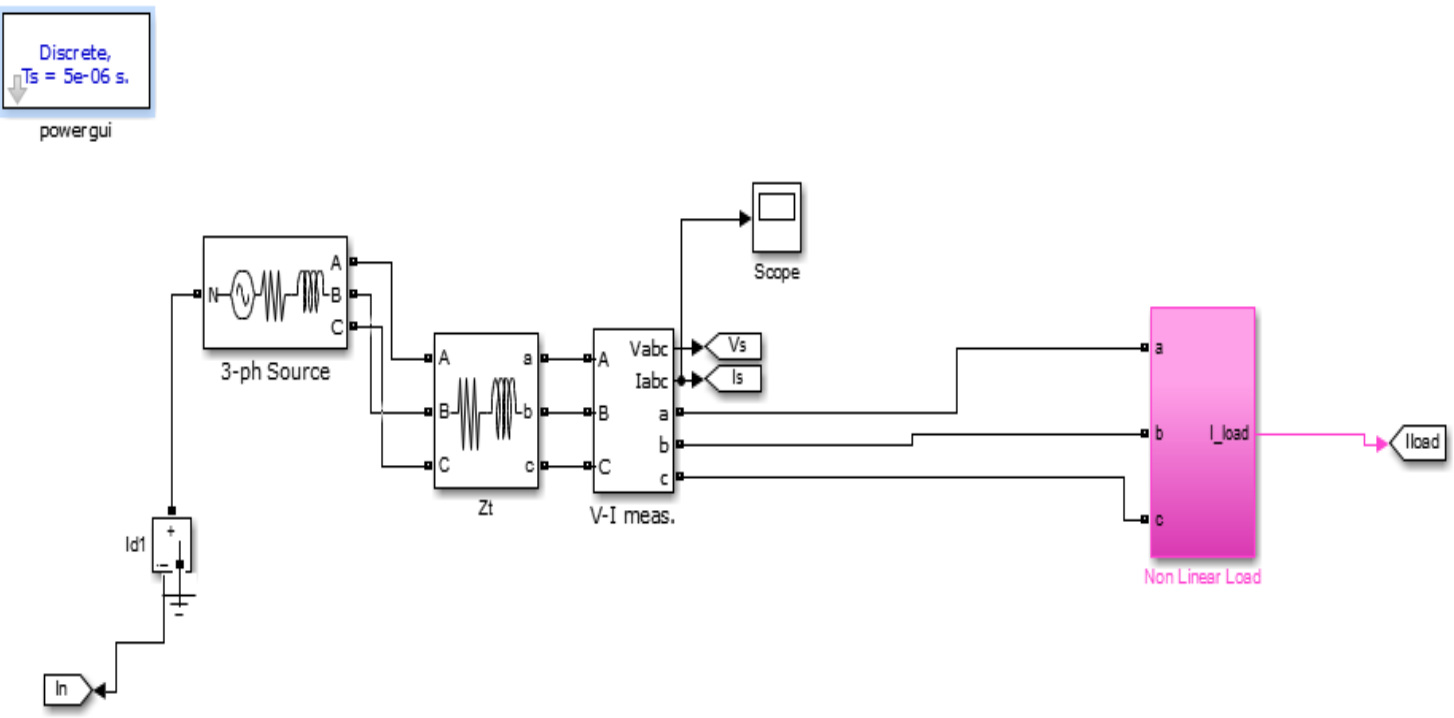

Figure 3: The distribution network Simulink model with linear and nonlinear loads. 


\section{RESULTS}

Figure 4 reveals the three phase voltages $V_{a}, V_{b}, V_{c}$ with the maximum voltage of $300 \mathrm{~V}$ (rms value), the three phase current $I_{a}, I_{b}$ and $I_{c}$, and the three phase load currents both scaled to $1: 10$. A significant level of distortions are observed from Figure 4, indicating the existence of harmonics on the power distribution network.

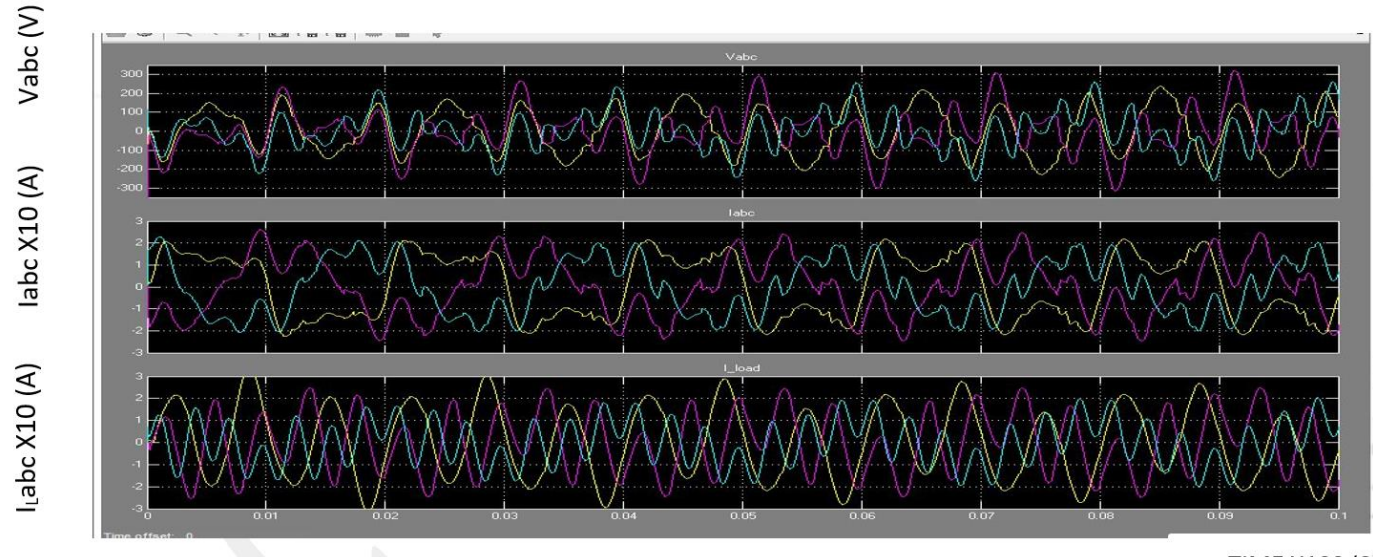

Figure 4: Waveforms obtained from the Scope.

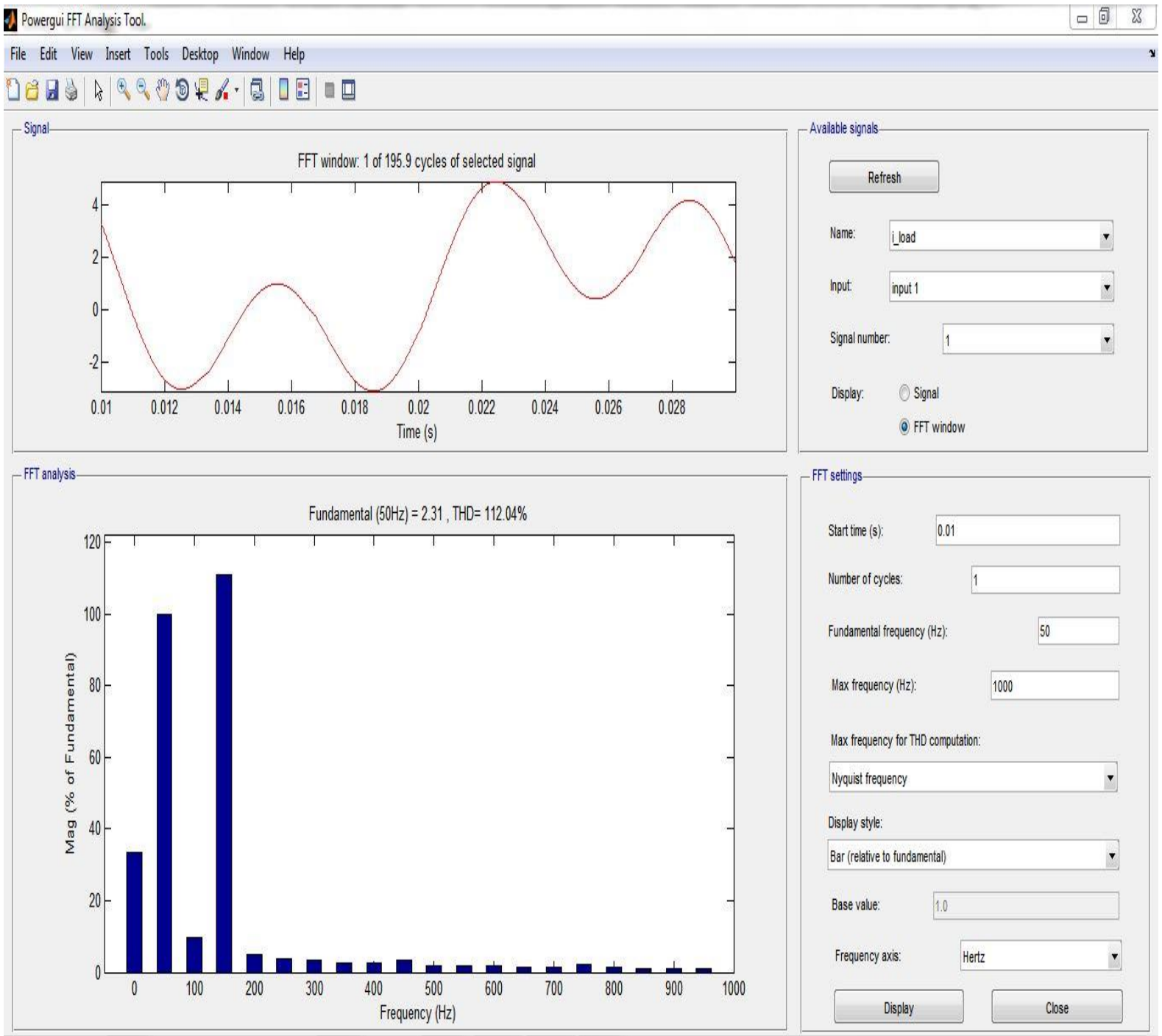

Figure 5: Fast Fourier Transform (FFT) Analysis of the Distribution Network with Nonlinear Loads 


\section{CONCLUSION}

The system is observed to be unstable with unperiodic oscillations; the percentage level of distortion due to the harmonics i.e. THD is $112.04 \%$ at maximum. This is a major deviation from the IEEE standard 519-1992 specification of 5\% maximum for distribution network below 69KV. The deviation is due to non-ohmic characteristic of the component elements that constitutes nonlinear load and due to higher frequencies at which such loads operate compare to the source frequency.

\section{REFERENCES}

[1] J.J. Marcuello, F. J. Arcega, I. Plaza and F. Ibáñez, "A Review of Teaching Power System Harmonics," Promotion and Innovation with New Technologies in Engineering Education, Spain, pp. 1-5, 2011.

[2] H. Xuemei and Z. Yongmei, "Generation and Harm for Power System Harmonics," in Proceedings of Fifth International Conference on Intelligent Computation Technology and Automation (ICICTA), IEEE Computer Society, pp. 553-555, 2012.

[3] H. A. Attial, M. El-Metwallyl and O. M. Fahmy, "Harmonic Distortion Effects and Mitigation in Distribution Systems," Journal of American Science, 6 (10), pp. 173-183, 2010.

[4] M. C. Pacis, J. M. Martinez Jr. and J. V. Tecson, "Modeling and Simulation of Active Power Filters for Harmonic Compensation, Voltage Sags and Swells Mitigation and Power Factor Correction," in Proceedings of the World Congress on Engineering and Computer Science Conference, San Francisco-USA, Vol. (3) - No. (4), pp. 1015 1020, 2010.

[5] B. Kumar, "Design of Harmonic Filters for Renewable Energy Applications," M. Sc. Thesis, Department of Wind Energy, Gotland University, Sweden, 2011.

[6] M. R. Arif, F. Mahmood, M. Hashmi and S. Hanninen, "Application of passive filters to mitigate power quality problems caused by induction furnaces," in Proceedings of IEEE International Conference on Condition Monitoring and Diagnosis, pp. 1227-1230, 2012.

[7] A. Y. Abdelaziz and S. F. Mekhamer, "Sources and Mitigation of Harmonics in Industrial Electrical
Power Systems: State of the Art", The Online Journal on Power and Energy Engineering, Vol 3, No 4, 2012.

[8] Z. A. Memon, M. A. Uqaili, and M. A. Unar, "Harmonics Mitigation of Industrial Power System Using Passive Filters," Mehran University Research Journal of Engineering and Technology, Volume 31, No. 2, pp. 355 - 360, 2012.

[9] I. I. Mujawar, D. R. Patil, and I. I. Mujawar, "Reactive Power Compensation and Harmonic Mitigation of Distribution System using SAPF Compensator," International Journal of Engineering Science and Innovative Technology, Volume 2, Issue 3, pp.494 - 502, 2013.

[10] S. Gupta and P. Gupta, "Harmonics Mitigation Using Active Power Filter," International Journal of Advanced Computer Research, Volume 3, Number 2, Issue-10, pp. 116 - 120, 2013.

[11] P. Tamilvani and K. R. Valluvan, "Harmonic Mitigation in Various Levels of Multilevel Inverter with Different Loads," International Journal of Innovative Research in Electrical, Electronics, Instrumentation and Control Engineering, Vol. 2, Issue 9, pp. 1989-1996, 2014.

[12] M. Kiran, L. P. Kumar, N. S. Rao and P. Veeranjaneyulu, "Design And Analysis of a 24pulse AC-DC Power Converter by Employing a Pulse Doubling Technique for Asynchronous Drive," International Journal of Conceptions on Electrical and Electronics Engineering, Vol. 3, Issue. 1, pp. 8-12, 2015.

[13] S. Molaei, S. Jalizade and M. Mokhtarifard, "Multiobjective Optimal Design of Passive and Hybrid Active Power Filter Based on Bacterial Foraging Optimization Algorithm," Journal of Electrical Engineering, volume 15, Edition 3, pp. 78 - 89, 2015.

[14] R.S. Rani, C. S. Rao and M. V. Kumar, "Analysis of Active Power Filter for Harmonic Mitigation in Distribution System," in Proceedings of International Conference on Electrical, Electronics, and Optimization Techniques (ICEEOT), pp. 1438 - 1446, 2016.

[15] G. Eduful and K. J. A. Atanga, "Evaluating the Performance of Harmonic Neutral Blocking Filter in ECG Electric Power Distribution System," in Proceedings of the World Congress on Engineering, London, U.K., vol. 1, pp. 363-366, 2017. 